\title{
CHALLENGES IN TEACHER TRAINING: students' assessment of the de chemistry licentiate degree course by the IFMT
}

\author{
Marcelo Franco Leão' \\ Eniz Conceição Oliveira² \\ Jaqueline Moll3
}

\begin{abstract}
Brazilian education faces many challenges, among which as highlighted in this text, is the need to prepare future teachers with a scientific and humanistic foundation, without neglecting contemporary aspects such as new technologies. The Chemistry Licentiate Degree course offered in the DE modality by the IFMT has contributed towards training teachers of this subject to work in Basic Education. Thus, the objective of this study is to reflect upon the educational conjuncture and identify how the course scholars assess the training process they are receiving. The study is of a descriptive and exploratory survey type from a quantitative approach, that took place during February and March 2017, with 57 course scholars taking part. The data was collected through an electronic form sent via Google Drive that contained 5 Likert scale closed questions to analyze 44 aspects of this training process and its elements. The methodology applied to analyze the collected data was consensus analysis. The results from the calculated scores point that the course meets academic expectations, with the following aspects being best assessed: comprehension of concepts and the effort to perform the activities (such as selfevaluation), selection of the contents covered (referent to the trainers), quality of label information (referent to the VLE), videos (as didactic materials), and questionnaires (as evaluation instruments). The only aspect that received no positive consensus in the assessment were the chats. Therefore, the assessment of the early DE chemistry teacher training is one way of reflecting upon the challenges education faces in contemporary times.
\end{abstract}

Keywords: Educational context. Early training. Training process.

\footnotetext{
1 Doutor em Educação em Ciências (UFRGS). Professor do IFMT Campus Confresa. Orcid iD: http://orcid.org/0000-0002-9184-916X.E-mail: marcelo.leao@cfs.ifmt.edu.br

2 Doutora em Química (UFRGS). Professora da UNIVATES. Orcid iD: https://orcid.org/00000003-0252-2243. E-mail: eniz@univates.br

3 Doutora em Educação (UFRGS). Professora da UFRGS. Orcid iD: https://orcid.org/0000-00015465-178X . E-mail: jaquelinemoll@gmail.com
} 


\title{
DESAFIOS NA FORMAÇÃO DE PROFESSORES: avaliação dos estudantes sobre
}

\author{
o curso de licenciatura em química em ead do IFMT
}

\section{RESUMO}

A educação brasileira enfrenta muitos desafios, dentre os quais destaca-se neste texto, a necessidade de preparar os futuros professores com embasamento científico e humanístico, sem descuidar dos aspectos contemporâneos, a exemplo das novas tecnologias. O curso de Licenciatura em Química, ofertado na modalidade EaD pelo IFMT, vem contribuindo com a formação de professores desta disciplina para atuarem na Educação Básica. Assim, o objetivo deste estudo foi refletir sobre a conjuntura educacional e identificar como os acadêmicos do curso avaliam o processo formativo que estão recebendo. $O$ estudo é do tipo levantamento descritivo e exploratório, de abordagem quantitativa, desenvolvido nos meses de fevereiro e março de 2017, cujos participantes foram 57 acadêmicos do curso. Para coletar dados, foi utilizado um formulário eletrônico, via Google Drive, contento 5 questões fechadas em escala Likert para analisar 44 aspectos deste processo formativo e seus elementos envolvidos. A metodologia utilizada para analisar estes dados coletados foi a análise de consenso. Os resultados dos escores calculados apontam que o curso atende as expectativas dos acadêmicos, sendo melhores avaliados os seguintes aspectos: compreensão dos conceitos e empenho na realização das atividades (como auto avaliação), seleção de conteúdos abordados (referente aos formadores), qualidade das informações nos rótulos (referente ao AVA), vídeos (como materiais didáticos) e questionários (como instrumento de avaliação). O único aspecto que não obteve consenso positivo na avaliação foi a realização dos chats. Logo, avaliar o processo de formação inicial de professores de química em EaD é uma maneira de refletir sobre os desafios da educação na contemporaneidade.

Palavras-chave: Contexto educacional. Formação inicial. Processo formativo.

\section{DESAFÍOS EN LA FORMACIÓN DE DOCENTES: evaluación de los estudiantes sobre la graduación de química en ead del IFMT}

\section{RESUMEN}

La educación de Brasil ha pasado por muchas dificultades, entre las cuales, en este texto, se destacó la necesidad de preparar a los futuros docentes con antecedentes científicos y humanísticos, así como con aspectos contemporáneos, como las nuevas tecnologías. La Graduación de Química, ofrecida en la modalidad EaD por el IFMT, ha contribuido a la formación de docentes para que puedan trabajar en Educación Básica. Por lo tanto, el objetivo de esta investigación fue reflexionar sobre la conjetura educativa e identificar cómo los estudiantes de la Graduación de Química evalúan su proceso formativo. Este estudio es una encuesta descriptiva y exploratoria, con un enfoque cuantitativo, desarrollada durante los meses de febrero y marzo de 2017, cuyos participantes fueron 57 académicos de la Graduación en Química. Para la recolección de datos, se utilizó un formulario electrónico, con 5 preguntas cerradas en la escala de Likert, para 
analizar 44 aspectos de este proceso formativo y sus elementos. La metodología utilizada para analizar estos datos fue el análisis de consenso. Los resultados de los puntajes calculados muestran que la Graduación coincide con las expectativas de los académicos, se han evaluado mejor los siguientes aspectos: comprensión de los conceptos y el esfuerzo para llevar a cabo las actividades (como autoevaluación), selección de los contenidos cubiertos (con respecto a los profesores), la calidad de la información en las etiquetas (sobre AVA), videos (materiales didácticos) y cuestionarios (como materiales de evaluación). El único aspecto que no logró ningún consenso positivo en la evaluación fue el de los chats. Por lo tanto, evaluar el proceso de formación inicial de los profesores de química en EaD es una forma de pensar sobre los desafíos de la educación en la contemporaneidad.

Palabras-clave: Contexto educativo. Formación inicial. Proceso formativo.

\section{INTRODUCTION}

Brazilian education is undergoing instances of transformations. The fast changes, the world of information and globalization constitute the current global setting that also presents great economic, cultural and social contrasts; such a setting requires that future teachers rethink their functions and the true purpose of education (LEÃO; OLIVEIRA; QUARTIERI, 2013). Within this conjuncture, teacher training is one of the core themes being currently discussed, since the effective changes are conveyed by those who mediate the teaching and learning processes.

To quote Ribeiro (1984, p. 8), "in order to solve a problem, it must be initially equated into its bareness and sized into its real magnitude". This means that for effective changes to occur in Brazilian education, its grievances must be thoroughly known in order that, once aware of its complexity, we may later seek alternative strategies to make changes. Thus, the need to investigate the training process of the future chemistry teachers who will work in Basic Education is justified.

Since the 1920s, several movements by intellectuals pointed towards the need to face the great problem in Brazil: "education" (MANIFESTO DOS PIONEIROS DA EDUCAÇÃO NOVA, 1932). Our governors did not deem it a priority, quite the contrary, it has always been viewed as a growing social problem since it was understood that the resources destined for education were expenses and not investments, under which view it would compromise the economy. 
If education is an existing problem in Brazilian society, means, mechanisms and strategies must be sought for universities to provide full training to those professionals who will have a direct influence in the education process: "the teachers". According to Ribeiro (1984), education's exposed nerve - professorship - is still being poorly prepared for its functions and discouraged. Teaching must be qualified and perfected, in addition to reclaiming its political responsibility that must not be silenced.

Within this context, teachers' social role must be rethought in addition to the challenges to be overcome to make schools attractive once more by providing students with a more involving, friendly and adequate environment where they may develop their cognitive skills and learn in a different way all the knowledge that pertains their lives (TEIXEIRA, 2007).

Another aspect to be considered is that in Brazilian schools each student's individuality is not usually taken into account, nor their yearnings, needs and perspectives. It is a school that is outside its era, since it still carries remains of traditional, elitist thinking, aimed at obtaining results and mass training, not taking our reality into consideration. If that were not enough, it can also be observed that the methodology adopted in the school universe ends up reproducing the hierarchical tiered relations by society (RIBEIRO, 1995).

In this sense, Piaget (1973) advocates that the teaching practice also be rethought so that teachers shift from being lecturers to being mediators in the education process, by stimulating research, the reconstruction and reinvention of pieces of information, and thus be able to construct new knowledge. The author further advocates that teacher training be developed within an active process, since such methods will allow to break the limits of information conveyance or content compliance in their subjects.

In the face of this situation, the following question arises: Within the current conjuncture, how is the early chemistry teacher training course occurring at the Mato Grosso Federal Institute of Education, Science and Technology (IFMT) offered in the Distance Education (DE) modality? 
In this sense, in order not to compromise the training of those professionals, it is believed that there is a need to include a space to reflect upon the social issues and adjustments to the educational theories to be applied in facing the challenges in contemporary society. Thus, the objective of this study is to reflect upon the educational conjuncture and identify how the above mentioned course scholars assess the training process they are receiving.

Initially, this text presents a historical retrospective on the Brazilian education system with emphasis on issues such as access to, continuity in and the quality of education offered to the popular classes. Following that, a reflection is made upon the education of scientific and humanistic bases, in addition to a discussion on the available technological tools for DE teacher training. The text further presents the methodological trail, as well as the results and their discussion, in addition to considerations from the reflection provided by the study. This study relied on financial subsidy of Call Notice 032/2019 from PROPES/IFMT and on support from the IFMT concerning the scholarship for the first author's doctoring (Call Notice 079/2016).

\section{THE TRAJECTORY OF THE BRAZILIAN EDUCATION SYSTEM}

The Brazilian population is constituted of different matrices and cultures. Within this mixture of races and cultures, the population was not given equal conditions to develop (RIBEIRO, 1995). It is known that, from the onset, the relationships among the three matrices that constitute the country Indigenous, African and Portuguese-Azorian - education was conceived as a privilege and a means of domination. That is, it must be considered that the education problems are rooted in historical issues of the nation.

Brazilian society is, up to a point, deformed, and bears within the historical scars and and malformations we suffered, and for those reasons we find it difficult to acknowledge, denounce, and overcome our limitations. The socially accepted idea that poor people are stupid became established as a truth, besides a socially irresponsible education policy. Actually, "Brazilian 
education teaches to view the past through the eyes of the slave owners" (RIBEIRO, 1984, P. 45).

Brazil was the last country in the world to revoke slavery. According to Ribeiro (1995), we may consider Brazil as being a land of slaves and slave owners, since the thinking of the dominant elite is to deprive the great masses of intellectual development to then continue to dominate and exert power over the subservient who would passively continue to do manual labor.

The truth is that we live in a country that historically has not complied with the task of offering quality education to its entire population. The Brazilian education system is incomplete and untimely, with its expansion having followed the industrialization in Brazil, i.e., the offering of public education in Brazil in the early 20th Century was developed to meet labor market demands (TEIXEIRA, 2007).

In the face of this education meltdown in the country, in 1932 there was the elaboration by great intellectuals such as: Fernando de Azevedo, Anísio Teixeira, Júlio de Mesquita Filho, Cecillia Meireles, and others, a statement titled "A Manifest by the New Education Pioneers" that formulated bases and guidelines to push the population and the government into action to defend education for everyone and not only for the elite as was the case. That manifest did not appear solely to point to the situation of education in Brazil, but to suggest points to make an improvement.

The main idea advocated was the creation of a single, public, free school, i.e., a new education policy was proposed with a singular sense and scientific and humane bases. The Manifest signatories attribute education with the role of transforming society and that this occurs in the midst of the diversity and plurality of social forces, that is, they believe its objective is to provide for the full development of human beings. (MANIFESTO DOS PIONEIROS DA EDUCAÇÃO NOVA, 1932).

In this sense, it is necessary that the entire population have the same opportunities so that education no longer serves class interests but the interests and needs of individuals, who are beings with rights and, above all, human. There must be nurturing that respects each persons' integrity and 
particular traits that also provides for the development of their faculties: intellectual, psychological, affective, political, cultural, and social.

According to Teixeira (1996), democracy will only exist in Brazil when schools are public, universal and free to be able to insert everyone in the society. Education must be thought of as having the capability of inserting persons into the world, and not as an instrument to meet the demands of class interests.

The 1932 Manifest pointed out some problems in the Brazilian education system, and although they were shown at that time, many of them have yet to be solved. It is worth mentioning their diagnostic: the economic and educational reforms are dissociated, as are the entities that maintain teaching; schools are isolated from the environment and do not prepare for life; teaching is merely literary, artificial and verbalistic; there is a lack of continuity and linkage between the schooling stages; there is no university, scientific research culture (MANIFESTO DOS PIONEIROS DA EDUCAÇÃO NOVA, 1932).

One other aspect to be considered is that during the last decades of the last century, according to Ribeiro (1984), there was unfathomed growth of the education machine that was merely quantitative, which made it impossible to attain the minimum quality conditions for schools to serve the population. The author states that we treat all students as if they were equal, with the same conditions. That goes to show that the school not only favors public employment, but remains elitist. It also mentions that the Brazilian education yield rates do not show the grievances that must be considered for us to find solutions for such problems.

To quote Ribeiro (1984, p. 65):

Only by observing the reality of each school, - the level of teacher training, the traits of the majority of students, the conditions of its existence within the community it serves - only from this solid base, with the most thorough and objective knowledge about it, is it possible to diagnose the problems that obstruct the elevation of the teaching level; seek realistic, feasible solutions. 
For this reason, we must first reestablish an educational concept, removing its formal, dual aspect that has prevailed for so long in our society in order to characterize it as a democratic process for individual cultivation and maturation of human beings in their totality (TEIXEIRA, 1996).

To quote Teixeira (2007, p. 125):

Common education for everyone cannot be circumscribed to alphabetization or mechanical conveyance of reading, writing and counting. It must form habits of sociability competence, of thinking and reflecting, of sensitivity and awareness.

The author advocates that the techniques of reading, writing and counting must be developed within a real context, as a social practice, for which skills are developed that are not possible to live without at present.

Considering the essentially political role of education, as advocated by the signatories, some actions were suggested at the time that are fully fitting in the current education context: reestablish trust and narrow relations between school and family; link up with other social institutions; resort to scientific techniques and instigate the students' creative activity; favor inner impulses to observe, experiment and create; get reorganized in a natural and social world; consider labor not as something that yields results, but a nurturing element (MANIFESTO DOS PIONEIROS DA EDUCAÇÃO NOVA, 1932).

According to Nóvoa (2009), contemporaneity requires from teachers the capacity to contextualize their practices for the school to take on its social role and thus value their true competence: the wholesome nurturing of human beings. The author states that it is necessary to involve other instances in the many activities and responsibilities that are not their competence, but that today are mistakenly entrusted to schools.

This way, it is understood that the school will organize itself around the actual life of the community by considering the local work, traditions, characteristics and peculiarities, The Greek thinking split education into intellectual and humanistic, which in this country reserved for the elite; and active or utilitarian, aimed at the poor so they perform manual labor 
(TEIXEIRA, 1996). They advocate the nurturing of life habits, that it be more practical than intellectualized.

The proposal Teixeira (2007) made is to offer the best possible schools, that would allow all persons to have a worthy life, especially those who were excluded from the education process or in unfavorable conditions for access and continuity, whether economic, cultural or social.

In the author's view, the face of the schools is the face of the nation, for, as long as education is not the priority of the nation, we shall not have actual human, social, scientific, cultural, political and economic development. In this sense, his struggle was for a school that is friendly to be in, provides opportunity for broad access to culture, offers not only basic training, but experiences with theaters, libraries, arts, workshops, laboratories, leisure and sports, and always seeking connections and wholesome nurturing.

During a long period, Brazilian education has been harnessed to education policies aimed solely at training people for the labor market and the alphabetization of voters. Even the offering of DE teacher training, despite appearing late in this country, held that intention. According to Giolo (2008), the public power took a long time to perceive this new trend, and only since 2005 that it began to organize and allow for the means to offer licentiate degree courses in the modality.

The above mentioned author criticizes the State's indifference in encouraging and elaborating public policies to promote DE teacher training as if he were protecting attendance teacher training. However, he also alerts that this process is to occur with plenty of effort, since a major portion of this training takes place virtually, but the professional activity will occur in a real context. In other words, teachers are not trained to work in DE, but in the classroom, where teaching and learning are constructed by means of interpersonal relations.

\section{EDUCATION ON SCIENTIFIC AND HUMANISTIC BASES}

The current conjuncture is no different to the context Anísion Teixeira 
and the signatories lived within, the pedagogical practice observed in most classrooms is far from following the transformations experienced by society, as it is set in traditional teaching methodologies that do not favor the production of knowledge, nor even social transformation (LEÃO; OLIVEIRA; QUARTIERI, 2013). What can be observed is an education that centers around complying with pre-established programs with no concern for the validity of such knowledge.

According to Moll (2015), school failure is also related to the inability of teachers to link established knowledge to student interests, which involve wishes, expectations, daily life, needs, in all, perspectives those youngsters have in relation to school and life.

In this sense, Teixeira (1957) presents education as science and art. In his view, education is a science, i.e., it requires thorough, systematized studying. In other words, it is the duty of education professional to investigate, study, register, seek results and socialize them for improvements and advancements in those important sciences to occur. More so because to prepare classes requires knowledge of the cause of what is being mediated (TEIXEIRA, 1957).

Yet according to the above mentioned author, education is an art, that is, teachers may not lack the sensitivity to perceive the context, consider students needs and anxieties, and discern the means to attain the objective of educating, which is nurturing human beings. Students must be looked at and their different contexts perceived.

Education is an art that presupposes exact and experimental knowledge related to human beings, not anatomically or physiologically, but psychologically (PIAGET, 1973). In other words, quality education is that aimed at the full development of man's wholesome personality.

For education is to actually develop its protagonist role in human nurturing, since it is through social interactions that we may find answers to face the great difficulties and solve the problems imposed by modern life. This way, new methods will appear to develop autonomy in the beings with rights and improvements to life quality and social interactions (FREIRE, 1996). 
Still according to Freire (1996), there is no teaching without research, nor is there research without teaching. Because when teaching, teachers continue pursuing, seeking to learn what they still do not know. In this sense, the author suggests that it is the duty of teachers to seek, question, provoke students to also become more restless and seek, by means of research, that what provoked them.

In official national documents, such as the Curricular Guidelines for Intermediate Education (BRASIL, 2006) and CNE/CP Notice nr. 02/2015, for example, it can be found that the teaching action presupposes the selection of contextualized school contents, which requires an understanding of the conceptions on education, scientific knowledge and learning.

That reason justifies the importance of providing, during early training, the development of the fundamental skills for teachers to relate reference contents (chemical concepts) and teaching strategies with reality (daily life) to then favor learning. This way, appropriate pedagogical tools are developed to establish connections between chemistry and life, which leads students to relate the studied contents with other fields of knowledge (LEÃO, 2014).

This way, it is important that educators encourage the perception of daily life situations that are observable and measurable, since the concepts brought to the classroom, according to Freire (1996), originate from their reading of a world whose meanings are pertinent to them. This pedagogical trend proposes teaching through correlations and information association.

After all, what use is there for students to "know" all the carbon cycle stages, for example, but not relate such knowledge with their daily life practice? By not relating this subject with the need to consume clean energies, or even not being concerned to use products from "Carbon Free" companies, students may be alphabetized for exams, but not literate for the world (LEÃO, 2014).

According to Penick (1998), working with scientific activities in teaching is a need, since the application of such pieces of knowledge allows for individual and social development. The inability to comprehend and utilize 
scientific knowledge in daily life represents a problem, as it does not allow citizens to enjoy those benefits.

In this sense, for there to be a relation between scientific knowledge and popular knowledge, it becomes necessary that there be significant intervention from education. Thus, according to Leão (2014), it is important that educators develop the perception of daily life situations, making it possible to establish relations between them and scientific knowledge.

Regarding such relation between science and life, Freire (1996, p.56) states that:

scientific and technological progress that does not fundamentally meet human interests, the requirements for our existence, loses, in my view, its significance. For every technological advancement there should be a corresponding real effort for an immediate response to any challenge that would place men's and women's joy of living at risk.

The concepts must have their applicability for life extracted to then use such knowledge to solve problems or, further still, be capable of explaining daily life phenomena by means of knowledge provided by science and technology. There must be an understanding of how new pieces of knowledge may be utilized by society (RICARDO, 2007).

With globalization, new concepts regarding education are listed in such a way that schools must also follow and broaden their horizons. From the above exposed, education is understood as the process that involves all of society, that has the purpose of wholesome nurturing human beings (GUARA, 2009). Such nurturing is essential for the development of beings and to ensure the enjoyment of other rights, thus being constituted as fundamental in itself.

Humanistically based nurturing is that, according to Teixiera (1996), in which knowing is not something to be accumulated, dogmatic or useless, but the art itself of doing things, solving daily life problems and, this way, turn individuals into real men. The fundamental idea is that every human action is a shared act, i.e., an associated action. Effective participation in the education process is what makes individuals capable of perceiving that their 
cognitive, physical and emotional development is a kind of joint development.

This wholesome human nurturing goes beyond teaching the sciences, therefore the school must be conceived as a large society for interacting, a space that is conducive to creation in which are built the fundamental learnings for life (MOLL, 2015). It is not merely an institution that simply prepares for life in a cold connection with the community and society, the school is life itself.

In this sense, it is necessary to promote effective teacher training, based on social interaction and autonomy as advocated by Freire (1996), to the point that the theories studied in the training process do not become just a bundle of words and the teaching practices mere activism.

\section{TECHNOLOGICAL TOOLS AVAILABLE FOR TEACHING AND LEARNING}

We live in a time that is marked by constant social changes brought on by scientific and technological advancements. Within this context, the education process needs to leverage its easy access to information and new educational technologies for students to comprehend the reality around them and be able to exercise their citizenship in a conscientious, autonomous, critical fashion (LEÃO; REHFELDT; MARCHI, 2013).

According to Silva \& Nuñez (2003), there is evident concern in official Brazilian education documents with the technological dimension in citizen formation. Thus, it is expected that early chemistry teacher training should allow for a reflection about the use of technologies to teach chemistry and how the players involved may explore such resources in the classroom aimed at new knowledge for didactic innovation.

Another aspect to be considered is that the offering of distance education courses was possible thanks to globalization and the democratization of Internet access, through which society is transforming the manner of accessing information. These resources are used for teacher training with the objective of reaching a public that is not served by the attendance modality. 
According to Valente (2014), the potential and possibilities that the Digital Information and Communication Technologies (DICT) offer the education and communication processes are enormous, such as the fast, agile way we access and share information with other people. However, the author alerts that those changes that occur in the field of communication do not happen at the same scale in the education field, that is, education is yet to appropriate all the resources available from DICT. In this sense, education should not remain alien to changes and every day it has been adhering to its didactic resources.

According to Almeida (2003), it was those new technologies that made it possible to potentialize and significantly develop Distance Education (DE) in the country, mostly with the offering of higher education courses. Flexibility of schedules and shortening of distances, that is, of spatial barriers, besides almost instant communication and exchange of materials resulted in DE broadening its actuation due to its interactive, dynamic potential for the construction of knowledge.

This way, the use of DICT in the educational medium has been gaining important spaces, such as offering teacher training courses in the DE modality, which is of a semi-attendance character. There are even Chemistry Licentiate Degree courses offered in DE, courses that until then would have been unthinkable in this modality for being a science of an experimental character.

This is why, more than ever, there must be an analysis of how this training process is occurring, that is, how are the courses on this practicalexperimental science being developed in the DE modality. To do so, it is necessary to reflect upon the available technological resources available in the Virtual Learning Environments (VLE) and how they may be used to teach and learn chemical concepts.

The resources contained in the VLE that use the Moodle Platform, for example, offer teaching institutions, trainer professors and course students countless possibilities by being interconnected networks that allow the players involved in the process to experiment with several pedagogical perspectives. 
In this sense, Torres \& Silva $(2008$, p. 3) state that in VLE,

[...] individuals may discover diversified media simultaneously and are thus able to integrate them into one activity. Some environments offer conditions that are adequate for the unfolding of interactive experiments regarding the relations with technology, and cooperative ones, regarding interpersonal relations.

This way, the DE professor may use VLE to "make available materials, texts, videos and audios, in addition to the activities. Students can access those resources from any location with Internet access, exchange ideas, materials, information; answer the activities, forums, among others" (FRANÇA, 2013, p. 20).

To corroborate the above mentioned thinking, Leão, Rehfeldt \& Marchi (2013, p. 49) advocate VLE as new education spaces that contribute towards the "involvement of students in the discussions, incentive to research, exchange experiences, improve communication, participant interaction, mutual assistance that characterized collaborative work, better understanding of the studied themes, among so many others".

\section{METHODOLOGICAL PROCEDURES}

This study is presented as a descriptive and exploratory research from a quantitative approach, and its information survey allows to better understand certain aspects of the object under investigation (GIL, 2008). The survey took place during February and March 2017 with scholars in this course.

As understood by Gatti (2004), educational problems exist that need quantitative data to be understood and characterized, that is, some data that are translated into numbers may reveal important aspects that were expressed by those involved, in this case the individuals that were investigated. To quote the author, the quantitative analysis methods "can be very useful to comprehend several educational problems. Further still, the combination of this type of data with data produced by qualitative methodologies may actually enrich the comprehension of events, facts, processes" (GATTI, 2004, p.13). 
This course utilizes the Moodle platform as the main technological learning medium. It allows to make the VLE available to the scholars, where the trainer professors place materials, guide studies, organize forums and chats for discussions, indicate reading materials, expose concepts, and propose evaluation activities (IFMT, 2012).

The invitation to take part in the research was sent to the electronic addresses of all 361 scholars enrolled during the period the study was being carried out. The invitation was sent more than twice, not only by those in charge of the study, but also by the course coordinator who stressed the importance of participating, in addition to providing a reminder on the VLE. From that universe, 57 scholars volunteered to take part in the investigation and filled in the form.

About the scholar term of consent to take part in the study, the invitation sent already stated the objectives, methods and contact of those in charge and requested that they access the form in case they accepted to volunteer to take part in the research. It is worth highlighting that the course coordinator and the general board of the Bela Vista Cuiabá IFMT Campus signed the letter of agreement authorizing the study to take place.

As the data collection instrument, an electronic form was used, via Google Drive, containing 5 closed questions that allowed to analyze 44 aspects (named A 1, ... A 44) in this training process. The question were elaborated in the multiple choice format, Likert (1932) scale style containing five points as alternative replies, with five meaning fully and one meaning insufficient.

According to Gatti (2004), by opting for using a collection instrument that is typical of quantitative research, such as forms, researchers have information available that allows for mapping what the investigated comprehend in relation to the investigation object, since "numbers, frequencies and measurements have some properties that outline the operations that may be done with them" (GATTI, 2004, p.13). 
The methodology used to analyze the collected data was consensus analysis, as proposed by Tastle \& Wierman (2006), that applies the following equation:

$$
\mu_{x}=\sum_{i=1}^{n} p_{i} X_{i}
$$

Where: $\mu_{x}$ represents the score; $p_{i}$ represents the probability or frequency; $X_{i}$ represents the weight of the alternative, ranging from 1 to 5 ; and $\sum_{i=1}^{n} p_{i} X_{i}$ represents the total sum of the product between the weight and probability.

According to this analysis methodology, the score is considered to be high when it is equal to or higher than 4 , and low when below 3. Thus, a high score is evidence of part or full agreement of the investigated in relation to the aspect being assessed, in turn, a low score means that the investigated disagree fully or partly in reference to the assessed aspect (TASTLE; WIERMAN, 2006). This way it is possible to trace the consensus of the investigated, that is, score calculation allows to trace a profile of the concordant and discordant replies. In other words, this method allows to comprehend the positioning of the investigated in a systematic, organized fashion, in addition to identifying the aspects that attained consensual understanding.

\section{RESULTS AND DISCUSSIONS}

The first question was aimed at the scholars making a general assessment of the training they are receiving in this DE Chemistry Licentiate Degree Course by the IFMT. The following aspects were considered: A 1: meets your expectations; A 2: qualifies for theory and for practice; A 3: offers quality teaching; $A$ 4: thoroughly trains the chemistry teacher; $A$ 5: prepares for the job marketplace; A 6: supplies updated, pertinent subsidies; A 7 : provides scholars with the instruments to teach in present times. Graph 1 shows the score obtained for each aspect assessed concerning the training process as a whole. 
GRAPH 1 - General assessment scores of the licentiate degree course

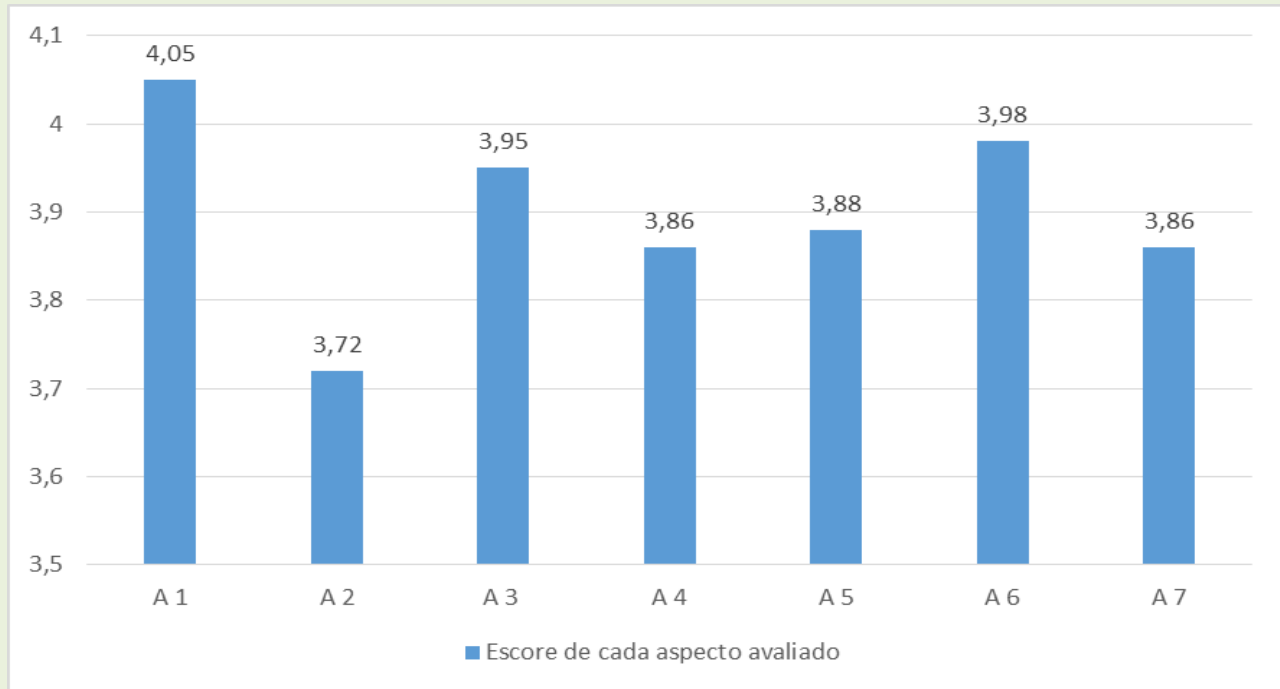

Source: Data obtained from the research (2017).

The results shown in the graph point that the scholars hold a positive view of this course, that it meets their expectations (A 1), not only from the high score (4.05), but also from the fact that $39 \%$ rated it 4 and $37 \%$ rated it 5 . Other aspects that were also well assessed are A 6 (supplies updated and pertinent subsidies) and A 3 (offers quality teaching) that obtained scores very close to 4 , also because those two aspects attained the maximum score from over $35 \%$ of scholars.

In reference to the high score for aspect A 1, it must be highlighted that meeting scholar expectations is essential for the education process. In this sense, it is possible to understand why the investigated scholars are satisfied with the course being offered, which is confirmed by aspects A 3 and A 6 .

This goes to reinforce the thinking that teachers build their professional identity through interaction with and the experience of reliable trainers who do not restrain their function to solely teaching classes, "but who present themselves as complex human beings and social players who embody interests, passions, doubts, failures, contradictions that are held of the role of teachers is that they intervene in an active manner" (PERRENOUD, 2005, p. 139). 
This way, it is believed that the training process may contribute to autonomy and conscientious, responsible participation in the classroom. This characteristic matches the alert made by Giolo (2008) that DE teacher training courses must be aware that the graduated professionals will be working in an actual classroom context, permeated by interpersonal relations and solid materials.

The second question was aimed at a self-evaluation by the investigated regarding academic performance. The following aspects were considered: A 8: achievements from these studies; A 9: utilization of available materials; A 10: concept comprehension; A 11: interactivity with the VLE; A 12: participation in synchronous on-line activities (video conference, chats...); A 13: effort to perform asynchronous activities (forums, tasks...) and A 14: time availability. Graph 2 shows the scores obtained for the above mentioned aspects.

GRAPH 2 - Scholars' self-assessment scores

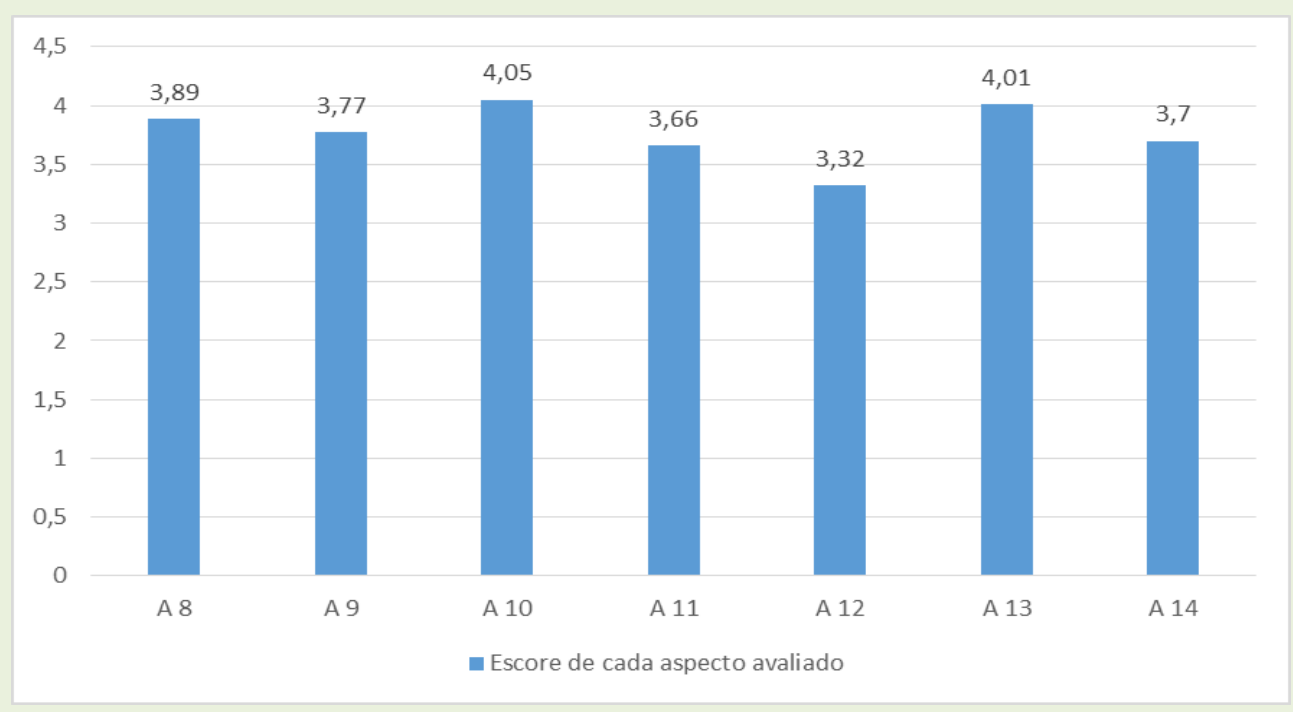

Source: Data obtained from the research (2017).

It may be perceived that the scores were high for two aspects relative to the scholars' self-assessment: concept comprehension (A 10) and effort to perform asynchronous activities, such as forums, tasks and others (A 13). 42\% of scholars attributed a 4 to aspect A 10 and $25 \%$ attributed the maximum 
score to this aspect. Aspect A 13 attained a 5 from $39 \%$ of the investigated and a 4 from other $35 \%$.

As advocated by Ribeiro (1984), in order that a situation be comprehended, above all else it is necessary to equate all the dimensions and elements involved, and in the process of this early DE teacher training the determining role of the scholar becomes evident. In their studies, Silva \& Nuñez (2003) highlight that this self-analysis that occurred along the training process trail assists in qualifying teachers to face the challenges of contemporary education, even with it being a learning situation permeated by technology.

The third question was aimed at having the scholars assess the development of the training process based on the following aspects: A 15: didactic sequence followed in the subjects; A 16: contents developed in classes; A 17: explanations and clarifications by professors when summoned; A 18: activities proposed by the professors; A 19: interaction between course students and professors/tutors; A 20: interaction between course students; A 21: Internet access; A 22: time period set for the activities; A 23: UAB hub equipment (laboratories, computers); A 24: practical/experimental activities; A 25: virtual laboratory; A 26: video conference; and A 27: printed material. Graph 3 shows the score attained for the aspects related to course development. 
GRAPH 3 - Scores related to course development

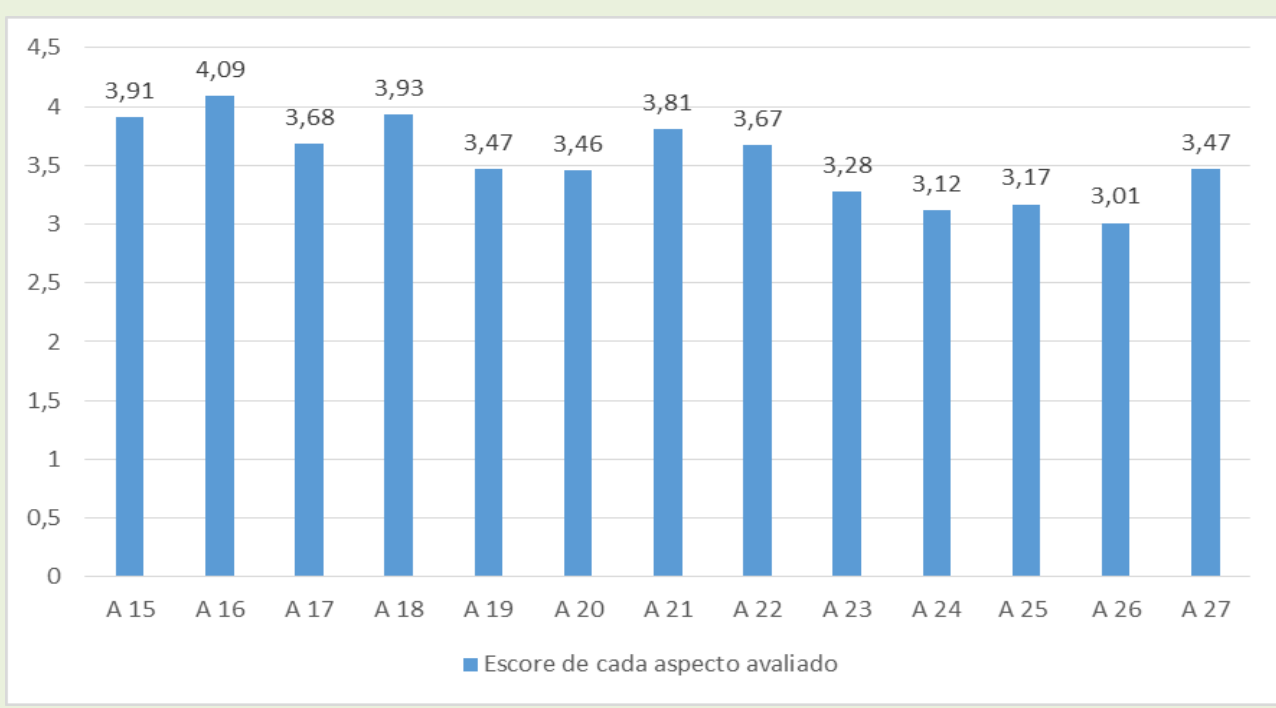

Source: Data obtained from the research (2017).

It may be perceived that regarding course development, only aspect A 16 (contents developed in classes) attained a high score (4.09). In this aspect, $40 \%$ of scholars attributed a 4 and other $37 \%$ rated it 5 . It is also worth pointing out that aspects A 18 (activities proposed by the professors) and A 15 (didactic sequence followed in the subjects) attained scores very close to 4 , and in both aspects $28 \%$ of scholars attributed the maximum score in the assessment. On the other hand, aspect A 26 (video conference) almost attained a low score, with $11 \%$ having attributed a 5 and other $44 \%$ a 3 .

It was also possible to perceive that $77 \%$ also rated 4 and 5 for the contents that were elaborated and carried out by the scholars together with the course professor and tutors. Under this same perspective, $68 \%$ of scholars rated the didactic sequence of the contents 4 and 5 , which goes to show that they understand how the subject contents have been organized.

The good relation between scholars and professors has a positive contribution toward successful teaching and learning, where $63 \%$ rated 4 and 5 for the activities proposed by the professors. Concerning teacher attention, $61 \%$ of scholars rated it 4 and 5 , and the same percentage for the aspect of the time period provided for performing the activities. 
These results reinforce the thinking of Piaget (1973), that training is a dynamic process that should be mediated daringly, to stimulate research so that the scientific concepts be comprehended in such a way as to be meaningful. It is worth highlighting that the author also advocates that teaching strategies, contents selected and relations established in the classroom are determining factors for attaining a successful education process.

The fourth question was aimed at the scholars assessing the virtual learning space and the resources utilized throughout the classes. The following aspects were considered: A 28: VLE layout; A 29: quality of the information contained in the classes (labels); A 30: texts/articles in DOC or PDF; A 31: classes elaborated on slides (PPT); A 32: computer animations (flash); A 33: audios; A 34: videos; A 35: directed links (URLs); A 36: selected file folders (directories); and A 37: electronic books in PDF. Graph 4 shows the score obtained for each aspect referring to the virtual learning space and the resources used throughout the classes.

GRAPH 4 - Assessment scores for the VLE and didactic resources

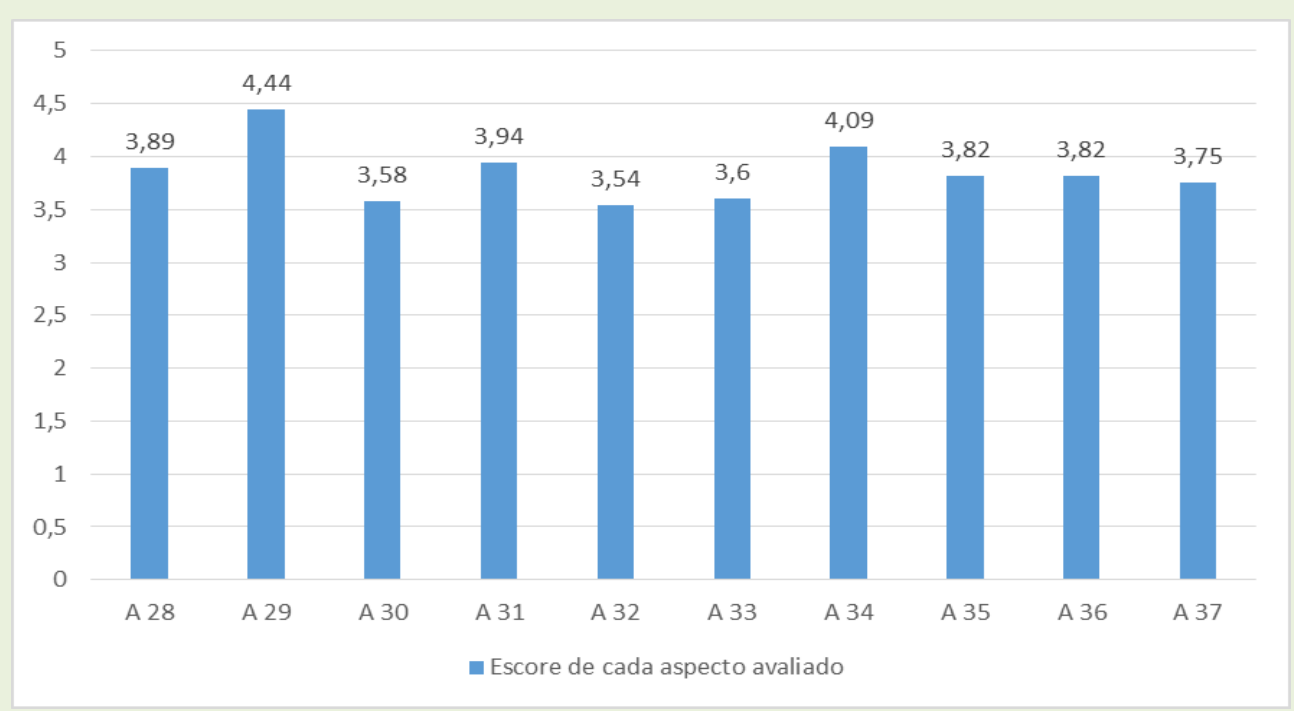

Source: Data obtained from the research (2017). 
Aspect A 29 (quality of the information contained in the classes, or the labels) attained the highest score among all assessed aspects (4.44). In this aspect, $54 \%$ of scholars attributed the maximum grade and other $35 \%$ a 4 . It may be perceived that the aspect was very well assessed by receiving $89 \%$ of rates 4 or 5 . This may be related to countless possibilities of sharing materials and information that DE allows (FRANÇA, 2013). Moreover, the author advocates that activity planning and presentation is very important for the process to receive the leadership and initiative of the students and thus breaking the traditional knowledge conveyance model.

Aspect A 34 (videos) also attained a high score (4.09). Maximum rates were attributed by $42 \%$ of the investigated and rate 4 by other $28 \%$ of scholars. The pedagogical resources that make use of audiovisual language received expressive acceptance amongst the scholars in this course of the DE modality.

The assessment of its elements and the way the VLE is organized (A 28), that is, the positioning on the layout of this virtual space is highly positive, with $74 \%$ of participants (vast majority) attributing rates of 4 or 5 for this aspect. An organized VLE is extremely important for the course, since it has a direct impact on training those teachers who will carry this planning and organization influence up to when they are actively teaching. It is worth highlighting now important such a reflection is during early training to be able to meet training needs so that chemistry teachers may be qualified to make use of technologies to favor teaching, as advocated by Silva \& Nuñez (2003).

The positive result from this assessment leads to the belief that the IFMT trainer professors are taking care when elaborating the VLE layout to make it practical and objective. This reinforces the thinking by Valente (2014) that when communication is facilitated through the use of DICT, it has a direct influence on the education process.

It may be observed that the score for aspect A 30 (texts/articles in DOC or PDF) was not very expressive (3.58), that is, those materials were not as well accepted as what was attributed to the videos or classes elaborated on slides. This finding corroborates what Leão, Rehfeldt \& Marchi (2013) reported, 
that contemporary scholars prefer images rather than text, that is, they are attracted by resources and materials that utilize a visual language.

On the other hand, aspects A 32 (flash computer animations) and A 33 (audios) also did not attain such expressive results as the videos, for example. This may be related to the fact that the audios do not involve graphic elements and the animations requiring interactivity with and initiative from the user of such didactic material, that is, they prefer ready made things, with the relations already established, such as what happens with videos.

The fifth and last question was aimed at scholars assessing the communication resources used and the learning evaluation instruments. The following aspects were considered: A 38: interactive lessons; A 39: wikis (collaborative texts); A 40: glossaries; A 41: chats; A 42: forums; A 43: questionnaires; and A 44: sending single files. Graph 5 shows the scores for the aspects related to the communication and evaluation resources.

GRAPH 5 - Scores for communication and evaluation instruments

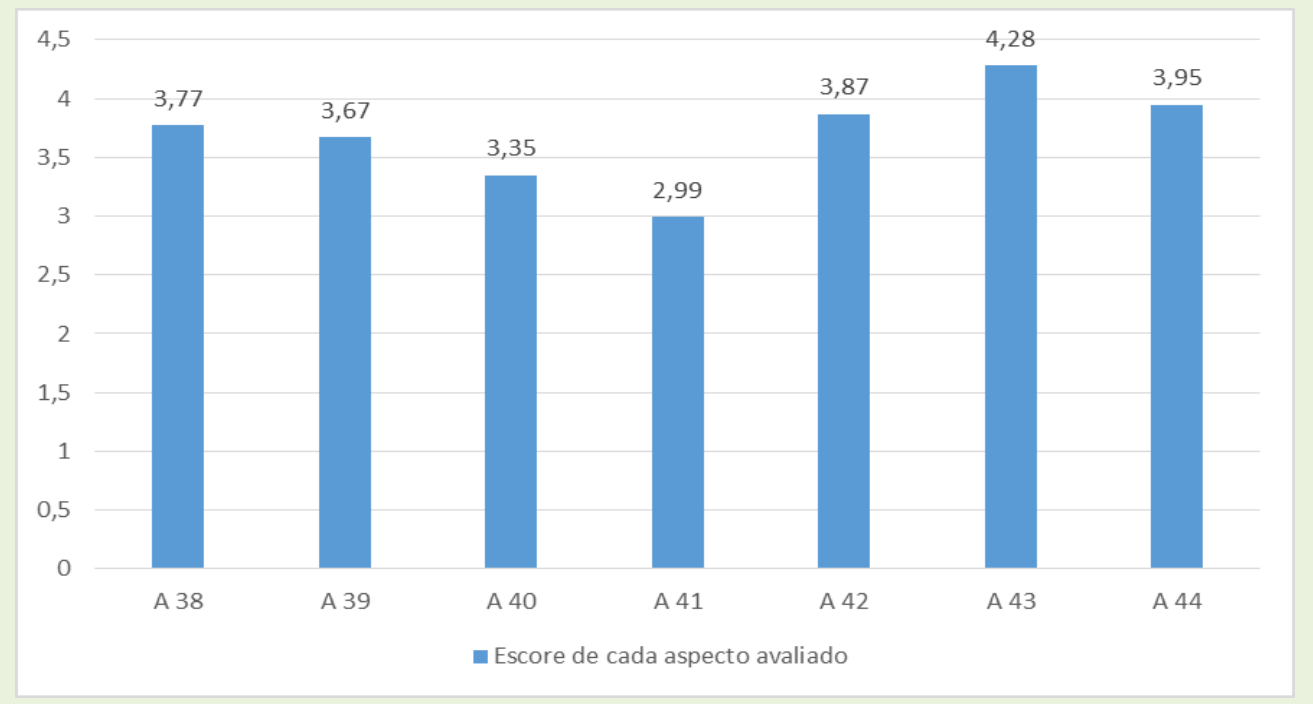

Source: Data obtained from the research (2017).

The only aspect among all those assessed in this study that obtained a low score was A 41 (2.99). The highest percentage (30\%) attributed a 3 for this aspect. $12 \%$ of the scholars attributed a 5 , and the same percentage attributed a 1 to the chats. These communication resources are very different from the forums with regard to the timing of connection among users who 
must be connected in synchrony, which allows it to be more dynamic to discuss the subjects/contents. However, such dynamics may also suffer variations according to the quality of the Internet being used and the schedule availability for all participants to be connected at the same time.

One alternative for the above mentioned difficulties that can be made available in digital educational environments are the forums. This communication resource, that may also serve as a learning evaluation instrument, allows professors and scholars to access asynchronously any previously created section to discuss several themes proposed along the course, cover current affairs and subjects related to the contents disclosed in the classroom (LOPES, 2004). In this education space, it is possible to comment on certain subjects that have been previously published by a person in charge, and thus promote the construction of knowledge by means of all users interacting.

Contrary to the chats, that were poorly assessed by the scholars, aspect A 43 (questionnaires) attained a high score (4.28). This aspect received the highest rate from $53 \%$ of scholars. One other aspect that was well assessed, and almost attained a high score, was A 44 (3.95). As to this evaluation instrument (sending single files), $40 \%$ of the interviewees attributed a 5 and other $26 \%$ a 4.

According to Leão, Rehfeldt \& Marchi (2013), there are plenty of contributions from DICT and resources available in the VLE for the scholar training process. To quote the authors, DE training "takes place by means of the tools and materials made available to students, showing that there are other possibilities of understanding a certain content by means of multimedia resources, such as audio, video, and animations" (LEÃO; REHFELDT; MARCHI, 2013, p. 49).

These results confirm the potential of DICT and Almeida (2003) Valente (2014), who advocate that such resources be broadly explored by teachers who will be working in Basic Education. In this sense, from the answers by the investigated scholars, everything shows that the development of this DE 
chemistry licentiate degree is favoring the construction of the chemistry teacher identity to work in contemporary times.

\section{FINAL CONSIDERATIONS}

One aspect that this study sought to stimulate was to open up reflections upon the current education context in the country from an understanding that it is a complex situation, highly influenced by, among other aspects, early teacher training. Those elements are responsible for mediating the teaching and learning processes. Thus, by revisiting the trail of the Brazilian education system, mostly in regards to access to, continuity in and quality of education offered to the popular classes, early scientifically and humanistically based teacher training is advocated for the Chemistry Licentiate Degree courses.

Furthermore, the assessment by scholars of the Chemistry Licentiate Degree course offered by the IFMT in the DE modality allows for the identification of how future teachers perceive their early training, that is, it was possible to obtain a parameter of how they assess the characteristics of the course as a whole, the methodology used and the relations established with the professors; self-criticism of their own performance, the VLE and its didactic resources, as well as the evaluation materials and instruments utilized throughout this early chemistry teacher training course.

The results allowed to establish that the course generally meets scholars' expectations, that being one of the aspects that attained a high score from the answers. Other well assessed aspects were: concept comprehension and effort to perform the activities pertaining to self-evaluation, the selection of contents covered in reference to the trainers, the quality of the information on the labels of the VLE, the videos among the didactic materials and the questionnaires as evaluation instruments. The only aspect that was not well assessed in the scholars consensus was the one related to the chats.

Among the well assessed aspects, the highest scoring one was the aspect related to the manner in which the VLE is being organized, with all its information organized in a clear, objective fashion, which contributes for the 
good development of the course. Additionally, it was possible to perceive that the investigated scholars prefer those resources that utilize audiovisual resources rather than texts.

Considering the proposition that early chemistry teacher training be scientifically and humanistically based, it is possible to believe that the scholars in this DE course are doubly favored, not forgetting that the modality allows to surpass physical and temporal barriers. Therefore, I believe the course is contributing towards training future teachers with chemical and didactic knowledge, among which the capability of linking strategies and technological resources with the education process.

\section{REFERENCES}

ALMEIDA, M. E. B. Educação a Distância na Internet: Abordagens e Contribuições dos Ambientes digitais de Aprendizagem. Educação \& Pesquisa. São Paulo: v.29, n.2, jul./dez.2003

BRASIL. Ciências da natureza, matemática e suas tecnologias / Secretaria de Educação Básica. Brasília: Ministério da Educação, Secretaria de Educação Básica, 2006. 135 p. (Orientações curriculares para o ensino médio; volume 2)

BRASIL. Parecer do Conselho Nacional de Educação CNE/CP 02/2015.

Diretrizes Curriculares para a Formação Inicial e Continuada. Disponível em: <http://pronacampo.mec.gov.br/images/pdf/parecer_cne_cp_2_2015_apro vado_9_junho_2015.pdf >. Acesso em: 12 ago. 2016.

FRANÇA, R. M. Introdução a EAD. São Luís: Universidade Federal do Maranhão.UNASUS/UFMA, 2013.

FREIRE, P. Pedagogia da Autonomia: Saberes necessários à prática educativa. São Paulo: Paz e Terra, 1996.

GATTI, B. Estudos quantitativosem educação. Educação e Pesquisa, São Paulo, v.30, n.1, p. 11-30, jan./abr. 2004.

GIL, A. C. Como elaborar projetos de pesquisa. 5. ed. São Paulo: Atlas, 2008.

GIOLO, J. A educação a distância e a formação de professores. Educação \& Sociedade (Impresso), v. 29, p. 1211-1234, 2008.

GUARA, I. M. F. R. Educação e desenvolvimento integral: articulando saberes na escola e além da escola. Em Aberto, Brasília, v.22, n.80, p.65-81, ab. 2009. 
IFMT. Projeto Pedagógico do Curso de Licenciatura em Química -

Modalidade a Distância. Comissão de Elaboração. Cuiabá: UAB/IFMT, 2012.

LEÃO, M. F.; OLIVEIRA, E. C.; QUARTIERI, M. T. A utilização de diversificadas estratégias de ensino associadas a um ambiente virtual de aprendizagem para potencializar as aulas de química. Revista Tecnologias na Educação, v. 9, p. 4, 2013.

LEÃO, M. F. Ensinar Química por meio de alimentos: possibilidades de promover Alfabetização Científica na Educação de Jovens e Adultos. 2014. Dissertação (Mestrado em Ensino). Programa de Pós-Graduação em Ensino PPGEnsino. Centro Universitário UNIVATES. Lajeado.

LEÃO, M. F.; REHFELDT, M. J. H.; MARCHI, M. I. O uso do ambiente virtual de aprendizagem como ferramenta de apoio ao ensino presencial. Abakós, $v$. 2, p. 33-51, 2013.

LIKERT, R.; A Technique for the measurement of attitudes. Archives of Psychology, n.140: p.1-55, 193.

LOPES, J. B. Aprender e ensinar Física. Braga: Fundação Calouste Gulberskian \& Fundação para a Ciência e a Tecnologia, 2004.

MANIFESTO DOS PIONEIROS DA EDUCAÇÃO NOVA DE 1932. Revista HISTEDBR On-line, Campinas, n. especial, p.188-204, ago. 2006. Disponível em: <http://www.histedbr.fe.unicamp.br/revista/edicoes/22e/docl_22e.pdf $\geq$ Acesso em: 28 mar. 2015.

MOLL, J. Educação integral: por um mundo onde todos caibam. Mundo Jovem: um jornal de ideias, Porto Alegre, p. 12 - 13, 01 abr. 2015.

NÓVOA, A. Para uma formação de professores construída dentro da profissão. In: 2009. p. 25-46. . Professores: imagens do futuro presente. Lisboa: Educa,

PENICK, J. E. Ensinando "alfabetização científica". Educar em Revista, Curitiba, n. 14, p.91-113. Editora da UFPR. 1998.

PERRENOUD, P. Escola e Cidadania: O apel da escola na formação para a democracia. Porto Alegre, Artmed, 2005.

PIAGET, J. Para onde vai a educação? Rio de Janeiro: Livraria José Olympo Editora/UNESCO, 1973.

RIBEIRO, D. Nossa escola é uma calamidade. Rio de Janeiro: Salamandra, 1984.

RIBEIRO, D. O Povo Brasileiro: A formação e o sentido de Brasil. 2. ed. São Paulo: Companhia das Letras, 1995. 
RICARDO, E. C. Educação CTSA: obstáculos e possibilidades para sua implementação no contexto escolar. Ciência e ensino, v. 1, número especial, 2007.

SILVA, M. G. L.; NUÑEZ, I. B. Os saberes necessários aos professores de Química para a Educação Tecnológica. REEC. Revista Electrónica de Enseñanza de las Ciencias, España, v. 2, n.3, p. 1-26, 2003.

TASTLE, W. J.; WIERMAN, M. J. Consensus and dissention: A measure of ordinal dispersion. International Journal of Approximate Reasoning. n. 45, p. 531-545, 2007.

TEIXEIRA, A. S. Ciência e arte de educar. Educação e Ciências Sociais. v.2, n.5, ago. 1957. p.5-22.

TEIXEIRA, A. S. Educação é um direito. 2. ed. Rio de Janeiro: Editora UFRJ, 1996.

TEIXEIRA, A. S. Educação não é privilégio. 7. Ed. Rio de Janeiro: Editora da UFRJ, 2007.

TORRES, A. A.; SILVA, M. O ambiente Moodle como apoio à Educação a Distância. In: $2^{\circ}$ Simpósio Hipertexto e Tecnologias na Educação: Multimodalidade e Ensino. Universidade Federal de Pernambuco, 2008.

VALENTE, J. A. A Comunicação e a Educação baseada no uso das Tecnologias Digitais de Informação e Comunicação. Revista UNIFESO: humanas e sociais, v. 1, p. 141-166, 2014.

Recebido em: 21 de novembro de 2018 Aprovado em: 04 de abril de 2019 